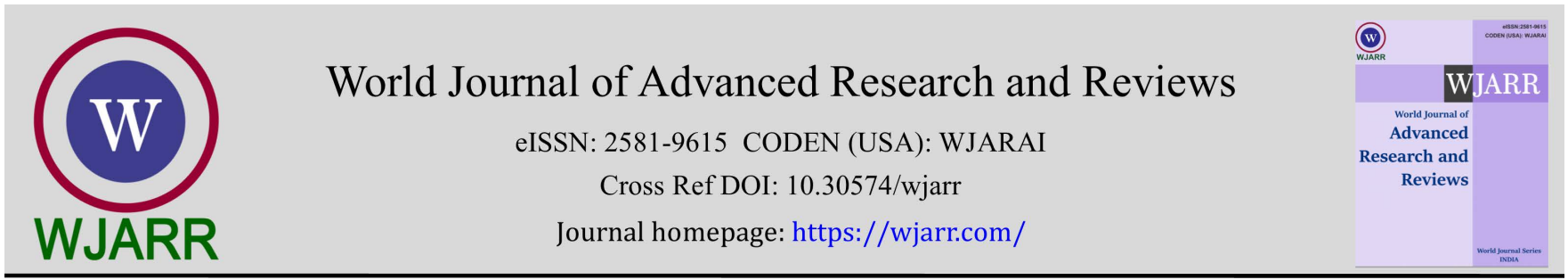

(RESEARCH ARTiClE)

Check for updates

\title{
Impact of phosphorus and sulphur nutrients as sole and in combination from organic sources and integration of organic and inorganic source on groundnut quality
}

\author{
Punitha Premanandarajah and Vassanthini Ratnarajah * \\ Department of Agricultural Chemistry, Faculty of Agriculture, Eastern University, Sri Lanka.
}

World Journal of Advanced Research and Reviews, 2021, 09(01), 297-302

Publication history: Received on 14 January 2021; revised on 22 January 2021; accepted on 24 January 2021

Article DOI: https://doi.org/10.30574/wjarr.2021.9.1.0029

\begin{abstract}
A pot experiment was conducted to study the effect of phosphorus and sulphur nutrients as sole and in combination from organic and integration of organic and inorganic sources on groundnut quality. Two studies were conducted to select best phosphorus and sulphur sources by using farmyard manure, poultry manure (PM), vermicompost and sewage sludge. There were six treatments in study one and two, including inorganic source of single super phosphate (SSP) and no phosphorus (control) in trial one and no sulphur (control) in trial two. They were replicated four times in a completely randomized design. Among them the selected best source poultry manure was combined with chemical fertilizer (CF) single super phosphate to supply phosphorus and sulphur by having six treatments (Control, 100\%PM, $75 \% \mathrm{PM}+25 \% \mathrm{CF}, 50 \% \mathrm{PM}+50 \% \mathrm{CF}, 25 \% \mathrm{PM}+75 \% \mathrm{CF}, 100 \% \mathrm{CF}$ ) and were replicated three times in a completely randomized design. The oil and protein content of kernels were increased as a result of phosphorus and sulphur. Poultry manure as a sole source of phosphorus and sulphur exhibited the highest oil and protein content. 25\% poultry manure with $75 \%$ chemical fertilizer as a combination exhibited the highest oil content (45.20\%) and $75 \%$ poultry manure with $25 \%$ chemical fertilizer as a combination resulted in the highest protein content (12.50\%) of kernels.
\end{abstract}

Keywords: Phosphorus; Sulphur; Ground nut; Oil content; Protein content.

\section{Introduction}

Oilseeds are energy rich crops and their nutrient requirement is high [1]. Despite the high nutrient requirement, they are mostly grown under energy-starved conditions. Limited or no use of plant nutrients is one of the most important contributing factors to the low productivity of oilseeds. The estimated nutrient removal by oilseed crops during $2003-$ 2004 was 3.24 million tonnes (N, P and $\mathrm{K}$ ), while the contribution to nutrient uptake from fertilizer was only 15.4 percent [2].

Soil fertility cannot be maintained with the application of inorganic fertilizers alone. Besides inorganic chemical fertilizers, there are several sources of plant nutrients like organic manures, crop residues, and industrial wastes. No single source can meet the growing nutritional needs of agriculture. To ensure sustainability of production, sources of organic and inorganic nutrients must be integrated. Deshmukh et al. [3] reported that if integrated nutrient management system is adopted, then higher levels of nutrient uptake by plant as well as its availability in soil could be maintained even after harvest of the crop. Furthermore, this might be due to organic manure and biofertilizer, which might have helped in maintaining the availability and supply of nutrients in soil to meet the plant requirement at the critical growth stages.

\footnotetext{
* Corresponding author: Vassanthini Ratnarajah

Department of Agricultural Chemistry, Faculty of Agriculture, Eastern University, Sri Lanka.

Copyright $(2021$ Author(s) retain the copyright of this article. This article is published under the terms of the Creative Commons Attribution Liscense 4.0.
} 
Phosphorus can be described as a "life mineral" due to its crucial role in metabolic and energy transfer reactions in living systems. Phosphorus plays a major role in the storage and transfer of energy and as a constituent of nucleic acid, phytin and phospholipids in plants. An adequate supply of phosphorus early in plant life is important for the reproductive parts of the plants. It plays an essential role in carbohydrate metabolism, fat metabolism and also in respiration of plants. Phosphorus deficiency is common in almost all the soils and crops in different states of the country. Available soil phosphate is often limited by fixation reactions, which convert the monophosphate ion to various insoluble forms. The availability of soil phosphate is enhanced by additions of organic manures, presumably due to chelation of polyvalent cations by organic acids and other decay products. Varalakshmi et al. [4] demonstrated that incorporation of farm yard manure along with inorganic phosphorus increases the availability of phosphorus and which is attributable to the reduction in fixation of water soluble phosphorus, increased mineralization of organic phosphorus due to microbial action and enhanced mobility of phosphorus. Specific attention should be paid to exploit the residual effect of phosphorus [5]. Application of P had significantly influenced the protein content of soybean seed. The highest protein content (41.66 per cent) was recorded with the application of $75 \mathrm{~kg}$ P205 ha-1 [6]. Field scale sulphur deficiencies in soils and plants are becoming increasingly significant. When a soil is deficient in sulphur, and this deficiency is not rectified, then the full potential of a crop variety cannot be realized regardless of the optimum supply of other nutrients and adoption of improved seeds or top class husbandry practices.

Sulphur deficiency is mostly reported in coarse textured soils, in soils having low organic matter, Dwivedi and Bapat [7] reported that $S$ treatment significantly increased the seed oil content and seed yield in soybean grown on $S$ deficient Vertisol. S availability in all the soil associations was significantly and positively influenced by organic matter [8]. Agrawal et al. [9] concluded that the seed and stover yield of sunflower increased up to the highest levels of P and S application. Research finding also indicated that the synergistic relationship between P and S was observed at $35 \mathrm{~kg} P$ and $50 \mathrm{~kg} \mathrm{~S}$ ha-1 resulting in highest seed, straw and oil yields in both the years. Protein content also increased with $\mathrm{P}$ and $\mathrm{S}$.

Application of inorganic manure in combination with organics increased the uptake of nutrients by both the crops as well as their availability in the soil. Information on the exact quantity of phosphorus and sulphur available to crops from the applied manures is scarce. The present study was conducted to find out the effect of phosphorus and sulphur nutrients as sole and in combination from organic and integration of organic and inorganic sources on groundnut quality.

\section{Material and methods}

There were three sets of studies, one on phosphorus sources, one on sulphur sources and the third on integration of phosphorus and sulphur through organic and inorganic sources.

In sole phosphorus and sulphur sources there were four organic sources (farmyard manure, poultry manure, vermicompost and sewage sludge) evaluated in comparison with the standard inorganic source of single superphosphate, all applied on equal P basis at $34 \mathrm{~kg}$ P205 ha-1 (in the phosphorus study) and on equal S basis at 75 $\mathrm{kg} \mathrm{S}$ ha-1 (in the sulphur study). The six treatments, including a no-P control in phosphorus study and no-S control in sulphur study were replicated four times in a completely randomized design.

In the phosphorus x sulphur integration study, there were six treatments $100 \%$ RDF to groundnut crop through poultry manure, $75 \%$ RDF through poultry manure and 25\% RDF through chemical fertilizers, 50\% RDF through poultry manure and 50\% RDF through chemical fertilizers, 25\% RDF through poultry manure and 75\% RDF through chemical fertilizers and 100\% RDF through chemical fertilizers), all applied on equal P basis at $34 \mathrm{~kg}$ P205 ha-1 and on equal S basis at $75 \mathrm{~kg} \mathrm{~S}$ ha-1. The six treatments, including a no-P and no-S control were replicated three times in a completely randomized design.

In all the three studies, seeds of groundnut were sown and after the germination routine cultural practices were adopted up to maturity and harvest. Then the pods were dried, shelled and the kernels were used for the analysis of oil and protein content.

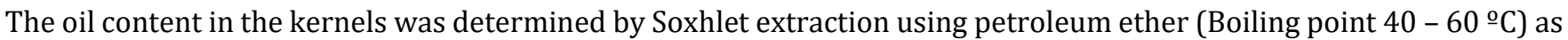
solvent as per the standard AOAC procedure [10]. Protein content of kernel was estimated by multiplying nitrogen content $(\%)$ of kernel with 6.25 . 


\section{Results and discussion}

\subsection{Effect of phosphorus sources on quality of groundnut}

\subsubsection{Oil content}

There was no significant impact on oil content in groundnut with respect to different P sources, but was significantly higher than control. The oil content was highest in poultry manure treatment (34.1\%) and was lowest in control (31.1\%).

The oil content in kernel was significantly influenced by phosphorus application. Phosphorus is known to be directly responsible for oil and albumin synthesis. The findings of the present investigation are in conformity with the findings of Ahmed and El-Araby [11]. Phosphorus also helped in synthesis of fatty acids and their esterification by accelerating biochemical reactions in glyoxylate cycle. The different sources did not significantly influence the oil content.

Table 1 Effect of phosphorus sources on quality of groundnut.

\begin{tabular}{|l|l|l|}
\hline Phosphorus sources & Oil content (\%) & $\begin{array}{l}\text { Protein content } \\
\mathbf{( \% )}\end{array}$ \\
\hline Control & $31.1^{\mathrm{b}}$ & $6.65^{\mathrm{f}}$ \\
\hline Farmyard manure & $33.0^{\mathrm{a}}$ & $12.34^{\mathrm{b}}$ \\
\hline Poultry manure & $34.1^{\mathrm{a}}$ & $12.83^{\mathrm{a}}$ \\
\hline Vermicompost & $33.1^{\mathrm{a}}$ & $11.82^{\mathrm{d}}$ \\
\hline Sewage sludge & $33.2^{\mathrm{a}}$ & $12.60^{\mathrm{c}}$ \\
\hline Superphosphate & $33.4^{\mathrm{a}}$ & $10.39^{\mathrm{e}}$ \\
\hline$P$ value & $<0.05$ & $<0.05$ \\
\hline
\end{tabular}

The values are means of replicates. Means with the same letter(s) are not significantly different from each other

\subsubsection{Protein content}

Phosphorus application significantly increased the crude protein percentage. Among phosphorus sources, poultry manure recorded the highest crude protein of $12.83 \%$. It was on par with sewage sludge treatment. Superphosphate treatment recorded the lowest value (10.39\%) but this was significantly higher than control (6.65\%).

The results revealed that protein content increased with the addition of phosphorus levels. Among phosphorus sources, poultry manure recorded the highest crude protein content of $12.83 \%$ and it might be attributed to the efficient assimilation of reduced nitrogen to aminoacids and protein. Kinfe et al. [12] observed a strong influence of phosphorus addition up to $46 \mathrm{~kg}$ P ha-1. Ernest et al. [13] confirmed that the phosphorus application leads to an improvement in the protein content in groundnut kernels.

\subsection{Effect of sulphur sources on quality of groundnut}

\subsubsection{Oil content}

Sulphur application showed significant improvement in the oil content in groundnut kernels as compared to control. But the sulphur sources among themselves were on par. The oil content ranged from $33.8 \%$ in superphosphate to $34.4 \%$ in poultry manure treated kernel. In control, the oil content was $31.3 \%$.

Sulphur source significantly influenced the oil content in kernel. The oil content in sulphur kernel was significantly higher than control. Radhamani et al. [14] supported this that the oil content in sesame was higher in treatments with sulphur application as compared to treatments without sulphur. This might de due to the role of sulphur in the synthesis of fat in plants. Tejeswara Rao et al. [15] also reported an increase in seed and oil yield due to sulphur application in groundnut. Different sulphur sources did not differ significantly with respect to oil content. The oil content or any quality parameters of oil seed crops is genetic factor and can't be altered much through agronomic practices [16]. 
Table 2 Effect of sulphur sources on quality of groundnut.

\begin{tabular}{|l|l|l|}
\hline Sulphur sources & Oil content (\%) & $\begin{array}{l}\text { Protein content } \\
\text { (\%) }\end{array}$ \\
\hline Control & $31.3^{\mathrm{b}}$ & $7.04^{\mathrm{d}}$ \\
\hline Farmyard manure & $34.0^{\mathrm{a}}$ & $12.83^{\mathrm{b}}$ \\
\hline Poultry manure & $34.4^{\mathrm{a}}$ & $13.68^{\mathrm{a}}$ \\
\hline Vermicompost & $34.1^{\mathrm{a}}$ & $11.53^{\mathrm{c}}$ \\
\hline Sewage sludge & $34.3^{\mathrm{a}}$ & $13.00^{\mathrm{b}}$ \\
\hline Superphosphate & $33.8^{\mathrm{a}}$ & $11.02^{\mathrm{c}}$ \\
\hline$P$ value & $<0.05$ & $<0.05$ \\
\hline
\end{tabular}

The values are means of replicates. Means with the same letter(s) are not significantly different from each other

\subsubsection{Protein content}

The crude protein content in groundnut kernel indicated that application of sulphur significantly increased the crude protein content over control. Poultry manure exhibited a significant increase in crude protein content (13.68\%). Crude protein content in organic manure treated kernels was significantly higher than the inorganic chemical fertilizer treatment. Among the organic manures, vermicompost recorded the lowest value (11.53\%). Control recorded a crude protein content of $7.04 \%$.

Analysis of protein content in groundnut kernels confirmed the increase in protein content with sulphur addition. It was supported by Santosh et al. [17] that increase in sulphur concentration is directly related to the formation of cysteine and cystine which favors the protein synthesis by wheat. Significant increase in the protein content in soybean seed has been reported with increasing level of sulphur application up to $75 \mathrm{~kg}$ ha-1 [18].

\subsection{Effect of phosphorus and sulphur sources on quality of groundnut}

Table 3 Effect of phosphorus and sulphur sources on quality of groundnut.

\begin{tabular}{|l|l|l|}
\hline $\begin{array}{l}\text { Phosphorus and } \\
\text { sulphur sources }\end{array}$ & Oil content (\%) & $\begin{array}{l}\text { Protein content } \\
\text { (\%) }\end{array}$ \\
\hline Control & $31.30^{\mathrm{e}}$ & $6.26^{\mathrm{d}}$ \\
\hline $100 \% \mathrm{PM}$ & $42.53^{\mathrm{bc}}$ & $10.60^{\mathrm{b}}$ \\
\hline $75 \% \mathrm{PM}+25 \% \mathrm{CF}$ & $43.50^{\mathrm{b}}$ & $12.50^{\mathrm{a}}$ \\
\hline $50 \% \mathrm{PM}+50 \% \mathrm{CF}$ & $41.57^{\mathrm{c}}$ & $10.46^{\mathrm{b}}$ \\
\hline $25 \% \mathrm{PM}+75 \% \mathrm{CF}$ & $45.20^{\mathrm{a}}$ & $10.75^{\mathrm{b}}$ \\
\hline $100 \% \mathrm{CF}$ & $39.73^{\mathrm{d}}$ & $10.04^{\mathrm{c}}$ \\
\hline$P$ value & $<0.05$ & $<0.05$ \\
\hline
\end{tabular}

The values are means of replicates. Means with the same letter(s) are not significantly different from each other

\subsubsection{Oil content}

Application of phosphorus and sulphur significantly increased the oil content of groundnut. Among the combination of sources, $25 \%$ poultry manure with $75 \%$ chemical fertilizer exhibited a considerable increase in oil content $(45.20 \%)$. The second best oil content was due to $75 \%$ poultry manure with $25 \%$ chemical fertilizer combination (43.50\%), which was comparable with the treatment that received poultry manure alone (42.53\%). The oil content in treatment that received poultry manure alone was comparable with the treatment that received $50 \%$ poultry manure and $50 \%$ chemical fertilizer combination.

The results of the present investigation indicated that the oil content of groundnut was significantly higher due to the application of phosphorus and sulphur. The beneficial effect of phosphorus and sulphur on oil content is due to the 
increase in linoleic acid content and probably due to the increase glucosides, which, on hydrolysis, produced higher amount of oil. Phosphorus and sulphur applications hastened the metabolic pathway of linoleic acid synthesis. The beneficial effect of phosphorus and sulphur application on oil content has also been reported by Mishra et al. [19] in mustard.

Combined application of poultry manure with chemical fertilizers significantly influenced the oil content than sole application. In this investigation $25 \%$ poultry manure with $75 \%$ chemical fertilizer exhibited a considerable increase in oil content (45.20\%). Poultry manure is rich in all nutrients. Vitale et al. [20] have confirmed the possibility of substituting recommended dose of fertilizers by poultry manure. Wamba et al. [21] confirmed that application of $12 \mathrm{t}$ ha-1 poultry manure increased the yield of groundnut. When poultry manure is combined with chemical fertilizer this might increase the availability of nutrients. In addition to nitrogen, phosphorus and sulphur other secondary and micronutrients also required for oil production which might have been rendered available [1].

\subsubsection{Protein content}

Phosphorus and sulphur applications significantly increased the kernel protein content. Maximum protein content was recorded in the treatment combining $75 \%$ poultry manure with $25 \%$ chemical fertilizer $(12.50 \%)$. This was followed by $25 \%$ poultry manure with $75 \%$ chemical fertilizer treatment $(10.75 \%)$ which in turn was on par with the treatment that received poultry manure alone $(10.60 \%)$ and the treatment that received $50 \%$ poultry manure combined with $50 \%$ chemical fertilizer (10.46\%). The treatment of chemical fertilizer alone recorded the lowest protein content (10.04\%) but this was significantly higher than in control (6.26\%).

The results with respect to protein content showed a significant influence due to the applied phosphorus and sulphur. This might be due to the increased uptake of nitrogen, which in turn might be incorporated in the protein molecule. Maragatham and Chellamuthu [22] reported that increased application of nitrogen, phosphorus and sulphur nutrients had positive and significant influence on seed yield and protein content of sunflower.

Combined effect of phosphorus and sulphur might have stimulated the proliferation roots and thereby enhanced the absorption of nitrogen which might have contributed for the increased protein content in seed. These results corroborated with the findings of Kisinyo et al. [23] in Leucaena

\section{Conclusion}

Phosphorus and sulphur nutrients as sole and in combination from organic sources and integration of organic and inorganic sources significantly increased the oil and protein content of groundnut kernels. In this experiment poultry manure as a sole source of phosphorus and sulphur exhibited the highest oil and protein content. 25\% poultry manure with $75 \%$ chemical fertilizer as a combination exhibited the highest oil content $(45.20 \%)$ and $75 \%$ poultry manure with $25 \%$ chemical fertilizer as a combination resulted in the highest protein content (12.50\%) of kernels.

\section{Compliance with ethical standards}

\section{Acknowledgments}

We thank Eastern University, Sri Lanka for its continued encouragement.

\section{Disclosure of conflict of interest}

The authors declare no conflict of interest

\section{References}

[1] Hegde DM. Nutrient management in oilseed crops. Fert. News. 2000; 45(4): 31-41.

[2] Hegde DM. Finding newer niches imperative. The Hindu Survey of Indian Agriculture, Kasturi \& Sons Ltd., Chennai. 2006; 66-69.

[3] Deshmukh KK, Khatik SK, Dubey DP. Effect of integrated use of inorganic, organic and biofertilizers on production, nutrient availability and economic feasibility of soybean grown on soils of Kaymore Plateau and Satpura hills. J. Soils and Crops. 2005; 15(1): 21-25. 
[4] Varalakshmi LR, Srinivasamurthy CA, Bhaskar S. Effect of integrated use of organic manures and inorganic fertilizers on organic carbon, available nitrogen, phosphorus and potassium in sustaining productivity of groundnut - finger millet cropping system. J. Indian Soc. Soil Sci. 2005; 52(3): 315-318.

[5] Kumaran S, Solaimalai A. Effect of organic manure and inorganic fertilizers on yield and nutrient uptake of irrigated groundnut. Crop Res. 2000; 20(1): 35-38.

[6] Shinde HP, Hiwarale JS, Mahulikar DN. Yield and quality of soybean (Glycine max) as influenced by sulphur and phosphorus application. J. Soils and Crops. 2007; 17(2): 350-353.

[7] Dwivedi AK, Bapat PN. Sulphur - phosphorus interaction on the synthesis of nitrogenous fractions and oil in soybean. J. Indian Soc. Soil Sci. 1998; 46(2): 254-257.

[8] Pandey SP, Singh RS, Mishra SK. Availability of phosphorus and sulphur in Inceptisols of Central Uttar Pradesh. J. Indian Soc. Soil Sci. 2000; 48(1): 118-121.

[9] Agrawal MM, Bharat Singh Verma, Chunchun Kumar. Effect of phosphorus and sulphur on yield N, P and S content and uptake by sunflower (Helianthus annus). Indian J. Agron. 2000; 45(1): 184-187.

[10] Horowitz W. Methods of analysis of the Association of Official Analytical Chemists, Washington DC. 1984.

[11] Ahmed Hala FS, El-Araby Magda MI. Evaluation of the influence of nitrogen fixing, phosphate solubilizing and potash mobilizing biofertilizers on growth, yield, and fatty acid constituents of oil in peanut and sunflower. African Journal of Biotechnology. 2012; 11(43): 10079-10088.

[12] Kinfe Tekulu, Gebeyehu Taye, Dereje Assefa. Effect of starter nitrogen and phosphorus fertilizer rates on yield and yield components, grain protein content of groundnut (Arachis Hypogaea L.) and residual soil nitrogen content in a semiarid north Ethiopia, Heliyon, 2020; 6(10).

[13] Ernest G, Kamara, Nana S, Olympio, James Y, Asibuo JY, Milton K, Kabbia, Keiwoma M, Yila, Abdul Rahman Conteh, Effect of Calcium and Phosphorus Fertilizer on Seed Yield and Nutritional Quality of Groundnut (Arachis hypogaea L.), International Journal of Agriculture and Forestry. 2017; 7(6):129-133.

[14] Radhamani S, Balasubramanian A, Chinnusamy C. Effect of sulphur application and foliar spray of nutrient and growth regulators on seed yield and oil content of sesame. Madras Agric. J. 2001; 88(10-12): 732-733.

[15] Tejeswara Rao K, Upendra Rao A, Sekhar D. Effect of Sources and Levels of Sulphur on Groundnut. Journal of Academia and Industrial Research. 2013; 2(5): 268-270.

[16] Salvatore La Bella, Teresa Tuttolomondo, Luca Lazzeri, Roberto Matteo, Claudio Leto, Mario Licata. An Agronomic Evaluation of New Safflower (Carthamus tinctorius L.) Germplasm for Seed and Oil Yields under Mediterranean Climate Conditions. Agronomy. 2019; 9(8): 468.

[17] Santosh Sahay, Birendra Prasad Singh and Birendra Kumar. 2005. Long term effect of manuring and S fertilization on productivity, sulphur content, nitrogen content and protein content of wheat. Crop Res. 30 (3): $364-368$.

[18] Ghosh PK, Hati KM, Mandal KG, Misra AK, Chaudhary RS, Bandyopadhyay KK. Sulphur nutrients in oilseeds and oilseed based cropping system. Fert. News. 2000; 45 (8): 27-40.

[19] Mishra V, Maurya D, and Gupta G. Effect of phosphorus and sulphur and their interaction on mustard crop. Asian Sciences. 2010; 5: 79-84.

[20] Vitale JD, Penn C, Park S, Payne J, Hattey J, Warren J. Animal Manure as Alternatives to Commercial Fertilizers in the Southern High Plains of the United States: How Oklahoma Can Manage Animal Waste, Integrated Waste Management - Volume II, Sunil Kumar, IntechOpen. 2011.

[21] Wamba OF, Taffouo VD, Youmbi E, Ngwene B, Amougou A. Effects of organic and inorganic nutrient sources on the growth, total chlorophyll and yield of three Bambara groundnut landraces in the coastal region of Cameroon. J. Agron. 2012; 11: 31-42.

[22] Maragatham S, Chellamuthu S. Response of sunflower to nitrogen, phosphorus and sulphur in Inceptisols. J. Soils and Crops. 2000; 10(2): 195-197.

[23] Kisinyo PO, Othieno CO, Okalebo JR, Kipsat MJ, Serem AK, Obiero DO. Effects of lime and phosphorus application on early growth of Leucaena in acid soils. African Crop Science Conference Proceedings. Uganda. 2005; 12331236. 